\title{
THE MARGINAL BORDER GROUP OF THE PORTTIVAARA LAYERED INTRUSION AND RELATED SULPHIDE MINERALIZATION
}

\author{
TAUNO PIIRAINEN, TUOMO ALAPIETI, RAUNO HUGG and \\ OLAVI KERKKONEN.
}

\begin{abstract}
PIIRAINEN, T., ALAPIETI, T., HUGG, R. and KERKKONEN, O. 1977: The marginal border group of the Porttivaara layered intrusion and related sulphide mineralization. Bull. Geol. Soc. Finland 49 (2): $125-142$.

Basic magma intruded between the Archean gneisses and the discordantly overlying volcanics in the Early-Proterozoic era, and, following Fenner's series of differentiation crystallized into a layered sequence of the Porttivaara massif. A relatively complicated border group developed between the layered sequence and the Archean gneisses consisting of the following units, from the bottom upwards: albite-quartz rock, contact gabbro and ultramafitolites. The border zone contains sulphide dissemination which consists mainly of chalcopyrite, pentlandite and pyrrhotite. The sulphide dissemination formed during the intrusion of the magma, as contamination lowered the solubility of sulphides in the magma.
\end{abstract}

Tauno Piirainen, Tuomo Alapieti and Olavi Kerkkonen, Department of Geology, University of Oulu, SF-90100 Oulu 10, Finland. Rauno Hugg, Rautaruukki Co., SF-90100 Oulu 10, Finland.

\section{Introduction}

At the beginning of the 1960's Outokumpu Co. received several chalcopyrite and pentlandite bearing samples from the western part of Koillismaa (Northeastern Finland), from the area of the 'Syöte-type gabbros' (Fig. 1). On the basis of these samples, Outokumpu Co. commenced ore explorations in this area in 1962, carrying out geological mappings, geophysical surveys and diamond drillings. These investigations indicated that randomly disseminated sulphides of economically interesting concentrations exist at the bottom of the 'Syöte-type gabbro' bodies. Pilot plant concentration tests were run by Outokumpu Co., but as the results were discouraging, the investigations were terminated in the summer of 1968 .

The Koillismaa Research Project, which was established in the spring of 1971 to carry out exploration oriented basic geological research on the ore-critical belt of mafic intrusions from Syöte to Näränkävaara, continued to clarify the sulphide disseminations, using as a basis Outokumpu Co.'s earlier investigations. Outokumpu Co. had approached the problem from the point of 


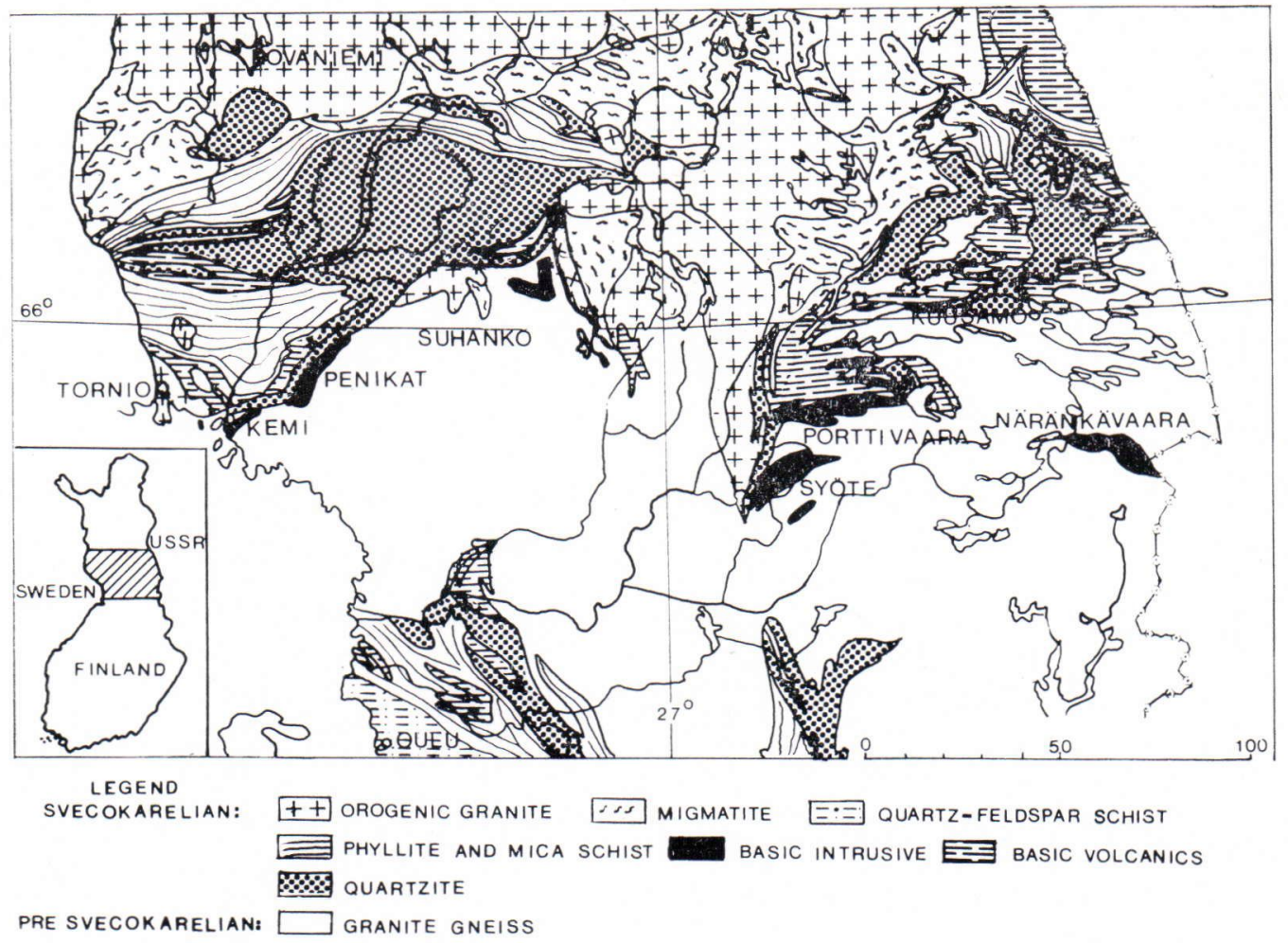

Fig. 1. Location of the Porttivaara massif on a map modified from (Simonen Geological Map of Finland 1960).

view of exploration and concentration, leaving the question of the genesis of the ore in the background. The Research Project, however, approached it as a part of the general geological evolution of the area, and an attempt was made to solve the genetic problems from this standpoint.

Most of the material for studying the sulphide dissemiated rocks originates from the bottom parts of the Porttivaara massif (Fig. 2). Geophysical surveys and diamond drillings were carried out by Outokumpu Co. on the border zone of the massif between Rusamo and Lavotta, and later on, in the summer of 1975, Rautaruukki Co. undertook geophysical surveys, pneumatic and diamond drillings at Lavotta. The Koillismaa Research Project has compiled a geological map of the marginal border group (Fig. 3) taking into account the outcrops and the above mentioned geophysical and drilling data. In connection with these investigations a great amount of data was gathered. These data serve as a basis for the present study, the purpose of which is to give a picture of the marginal border group of the Porttivaara massif, its sulphide dissemination, the relationship of the border group and the sulphide disseminations to the intrusion proper, and the genesis of the sulphide dissemination.

The topic of the present study is part of a much wider problem. Namely, does the magma, which produces ore deposits cuntaining paragenesis pyrrhotite-pentlanditechalcopyrite, have to be originally different in one way or another, or do the crystalli- 


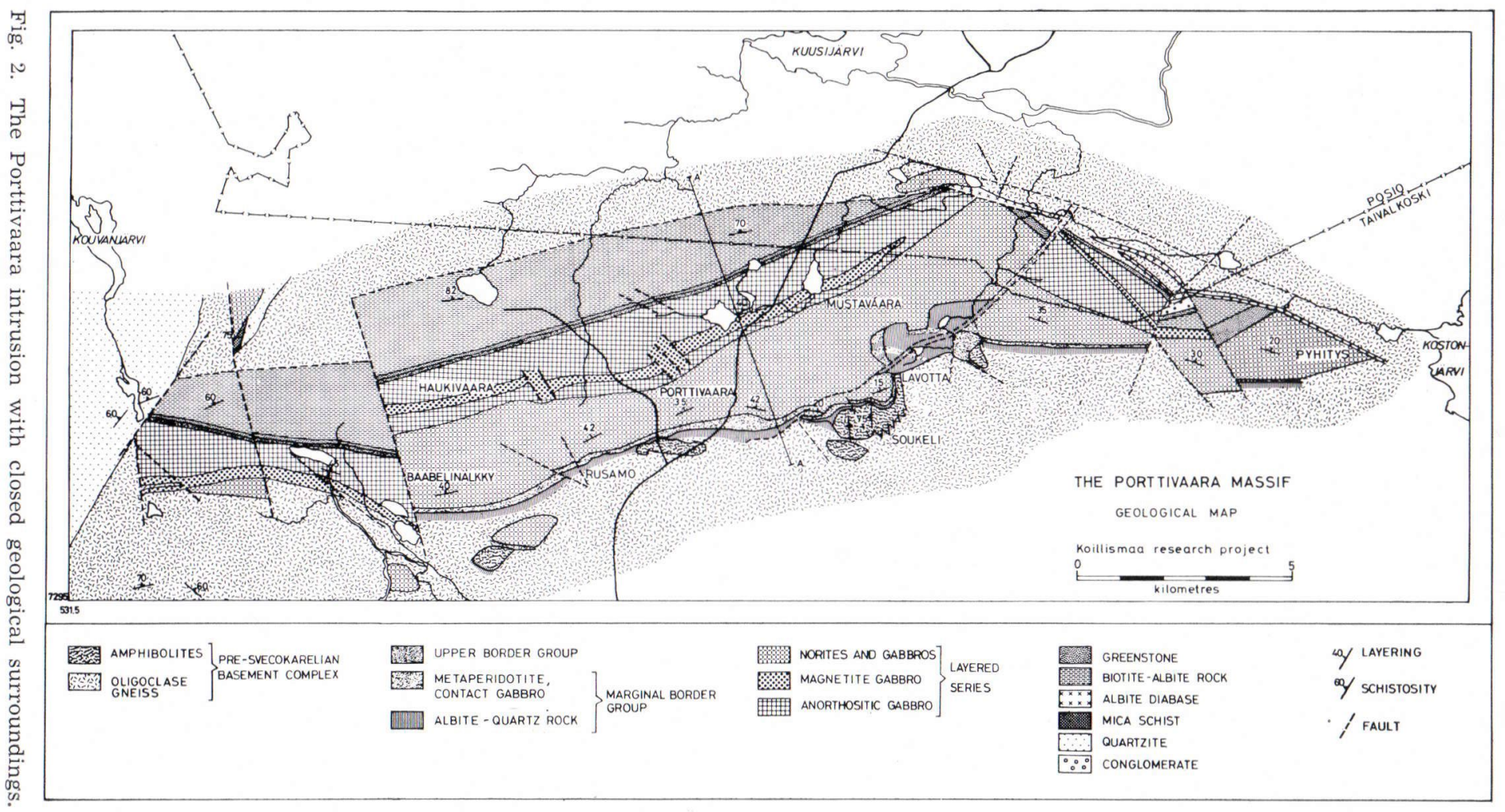




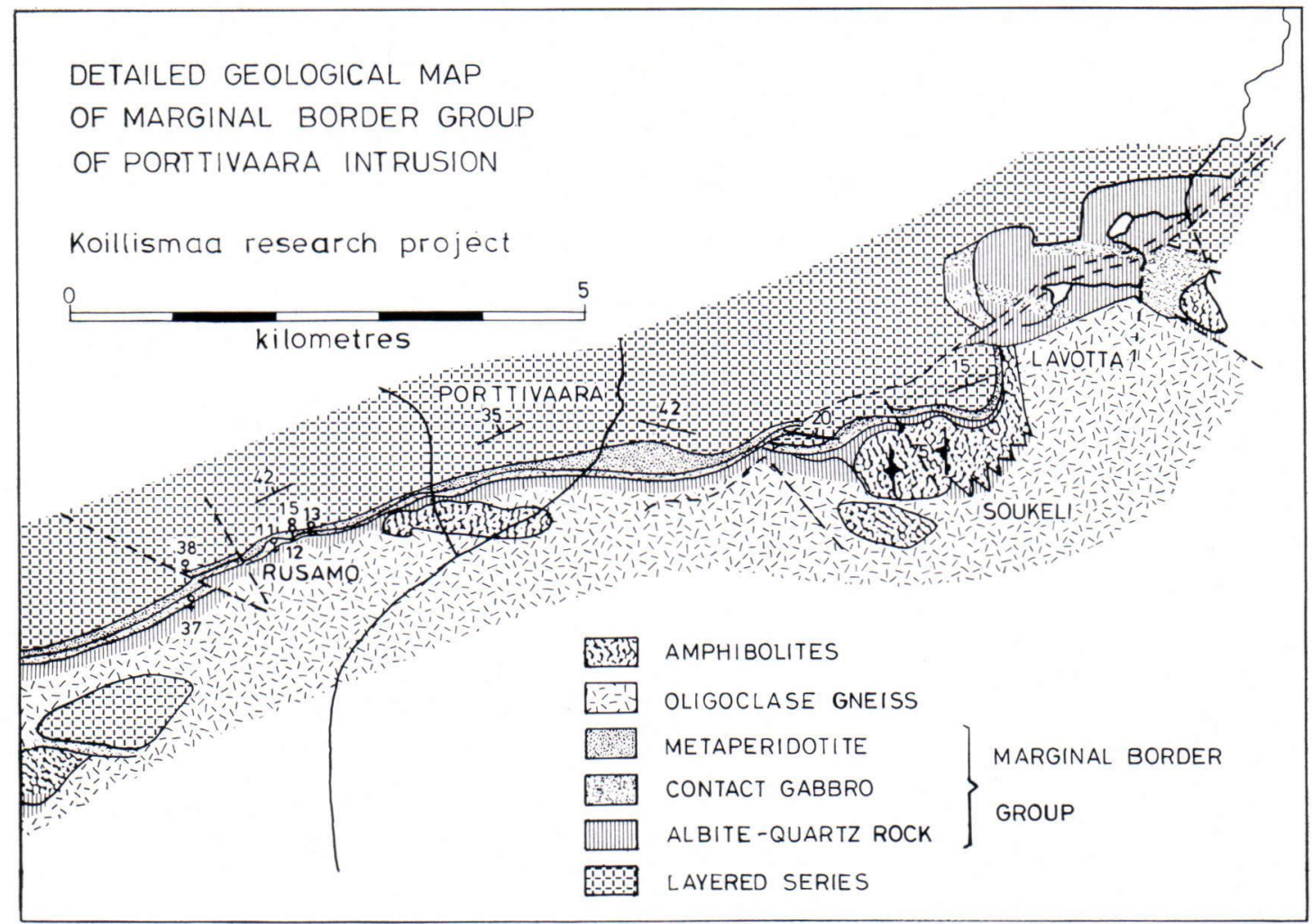

Fig. 3. The marginal border group of the Porttivaara intrusion between Rusamo and Lavotta.

zation conditions induce ore forming processes? If the latter alternative is accepted, a new question arises. How are the ore forming processes connected with the crystallization of magma, and is it possible to observe from a layered sequence the separation of sulphides from the silicate melt? This question is of great practical importance in the exploration of Ni-ores. The examination of this subject is backed by experimental studies on the solubility of sulphur, by which remarkable results have been achieved during the last few years (Maclean 1969; Haughton et al. 1974; Shima \& Naldrett 1975).

\section{The Porttivaara intrusion}

The 'Syöte-type gabbros' represent a layered intrusion, that intruded between the basement complex and the overlying volcanics, and was split into several separate blocks by later tectonic movements (Piirainen et al., 1974). Of these blocks, the Porttivaara body represents the most centrally located and the best known part of the intrusion, as can be seen from the numerous publications and unpublished studies (Ohenoja 1968; Piirainen \& Juopperi 1968; Juopperi 1970; Häkli 1971; Mäkelä 1975; Kerkkonen 1976; Isohanni 1976; Juopperi 1977; Piirainen et al. 1977).

The Porttivaara block forms a belt of mafic rocks appr. $30 \mathrm{~km}$ long and $4 \mathrm{~km}$ wide between the basement complex and the volcanics (Fig. 2). On the basis of the interpretation of gravimetric survey results, the thickness of the body is $2 \mathrm{~km}$ (Fig. 4). The strike of the layering and the igneous lamina- 


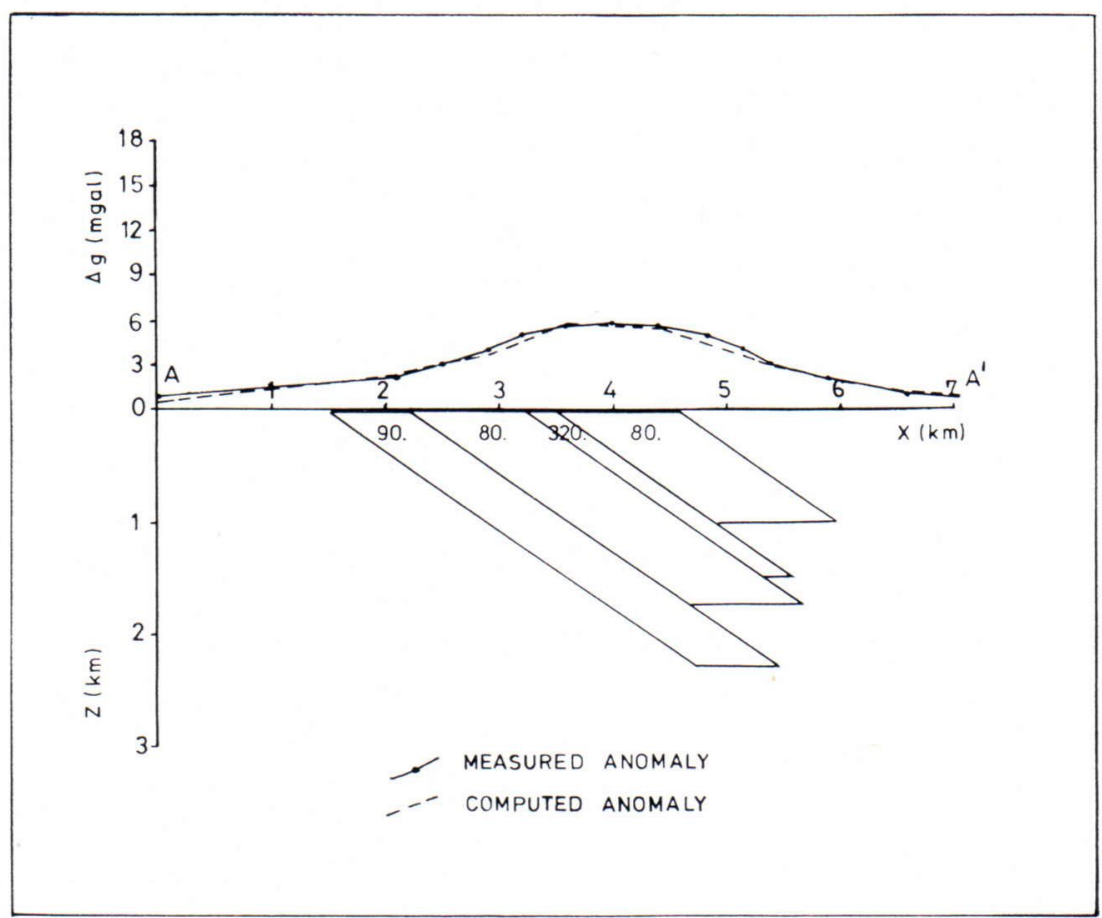

Fig. 4. An interpretation of gravimetric profile A-A' across the Porttivaara massif. Density contrasts in $\mathrm{kg} / \mathrm{m}^{3}$. Line $\mathrm{A}-\mathrm{A}^{\prime}$ is marked on the geological map (Fig. 2).

tion runs parallel to the long axis of the massif, or E-W, with a dip of $35^{\circ}-40^{\circ}$ to the north.

Border zones separate the body both from the overlying volcanics and from the basement complex rocks on the foot wall side (Fig. 5). On the basis of the mineral compositions and the rhythmic layering of the rocks the layered sequence can be subdivided downwards, using Streckeisen's (1976) terminology, as follows:

Anorthositic gabbro II

Magnetite gabbro

Anorthositic gabbro I

Gabbronorite III

Olivine gabbronorite

Gabbronorite II

Gabbro

Gabbronorite I

Olivine norite
The lower parts of the body contain different norites and gabbros, the constituent minerals of which are ortho- and clinopyroxene, plagioclase, and in some layers, olivine.

In the upper parts of the body plagioclase predominates over clinopyroxene, which occurs between the plagioclase crystals. In the lower part of the anorthositic gabbro there is a magnetite gabbro horizon, which contains an economically viable concentration of vanadium bearing ilmenomagnetite; the Mustavaara vanadium mine.

The chemical composition of the minerals changes regularly from the bottom upwards (Fig. 6). The Mg/Fe-ratio of the ortho- and clinopyroxenes and the olivine, and the Ancontent of plagioclase generally decreases upwards, with the exception of the anorthositic gabbro II, where the plagioclase may 


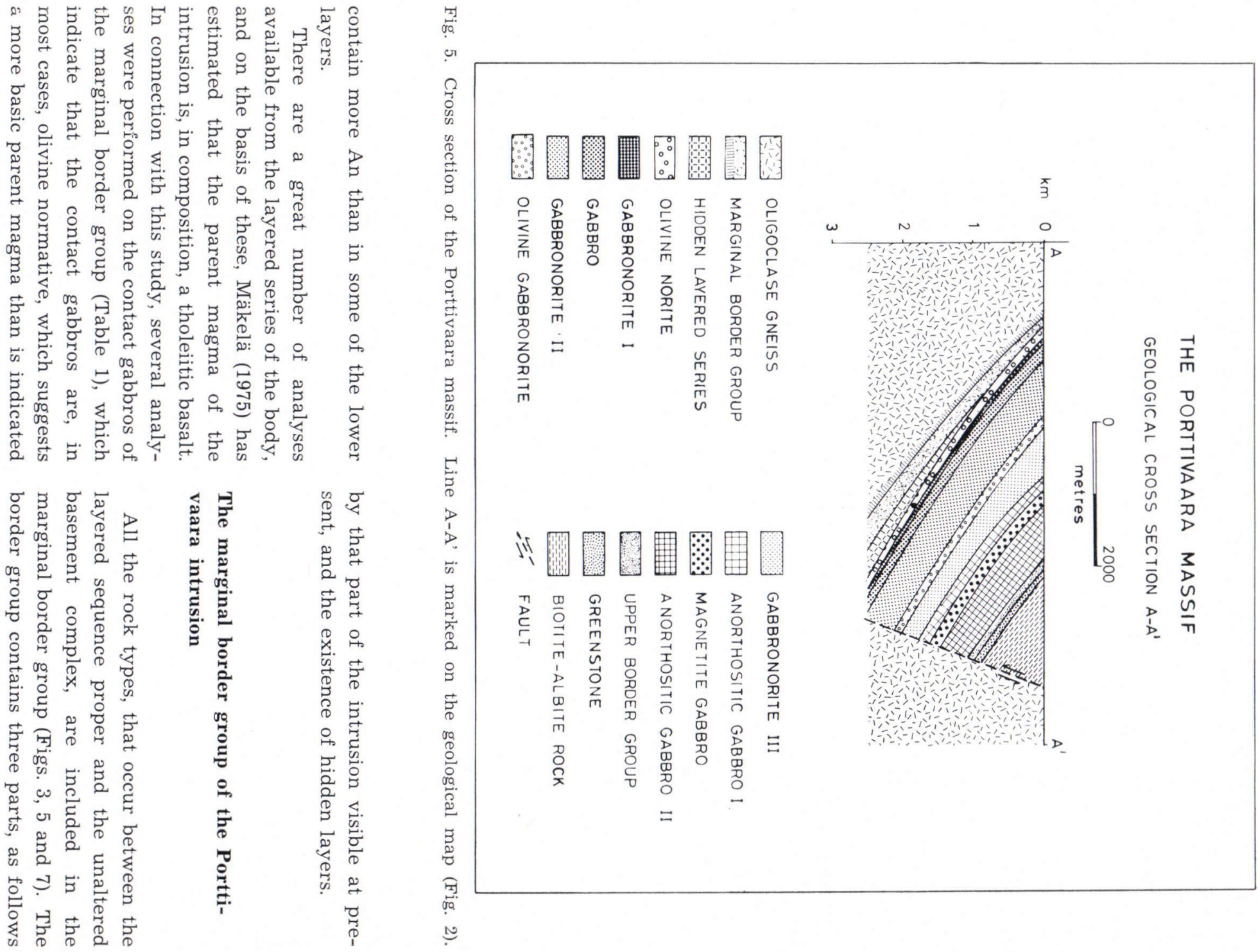



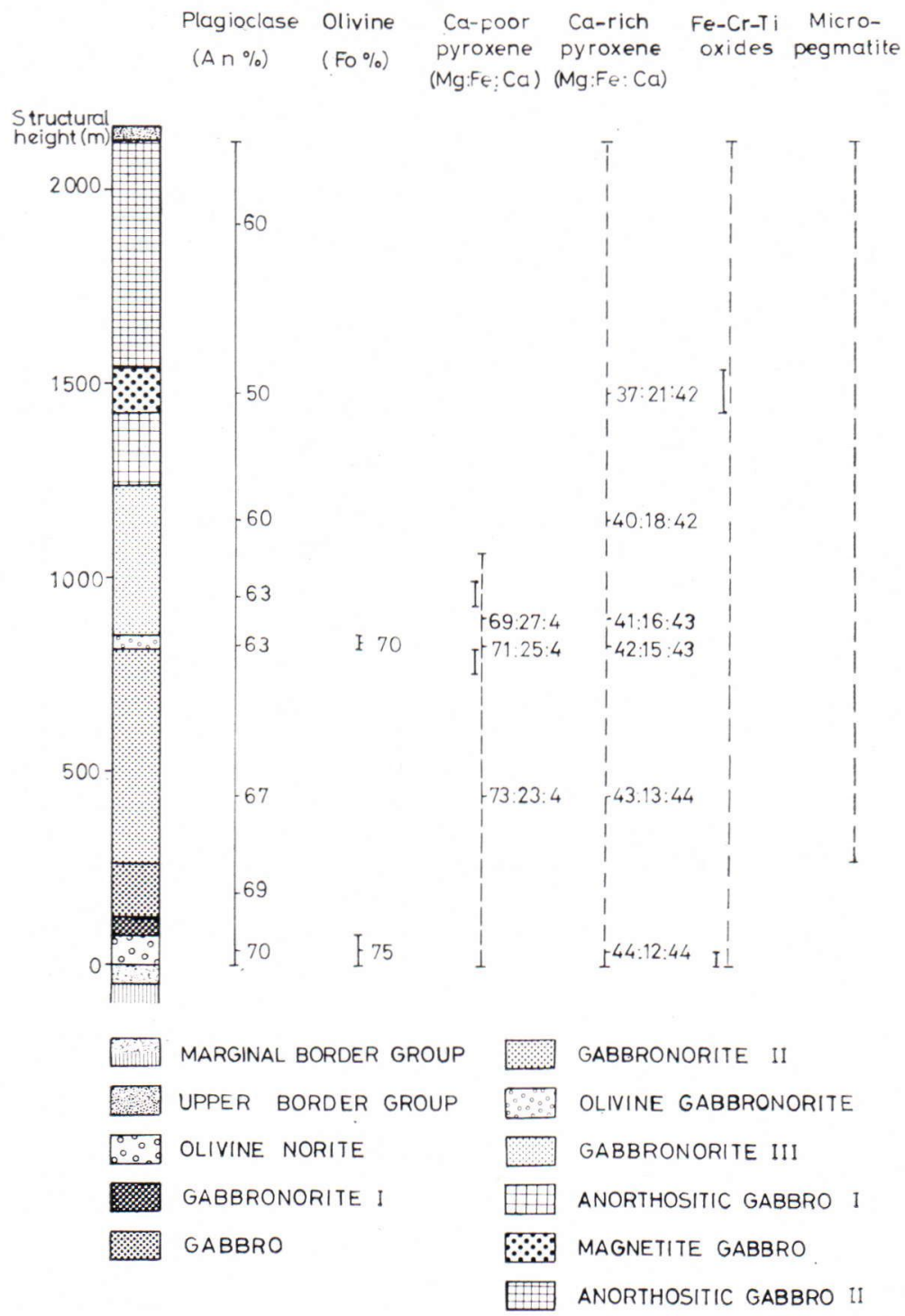

Fig. 6. Stratigraphic sequence of cryptic layering in the Porttivaara massif. The plagioclase cumpositions are based on optical determinations, the olivine and pyroxene compositions on microprobe analyses (Table 3). Cumulus minerals are indicated by solid lines, and intercumulus minerals by broken lines.

(from the bottom upwards): albite-quartz rock, contact gabbro and ultramafitolites. The true width of the border zone varies from $50-200 \mathrm{~m}$.

The dominant rock type of the basement complex is an oligoclase gneiss (Matisto 1958), the constituent minerals of which are: oligoclase, quartz and biotite. The chemical composition of this rock resembles that of graywackes (Table 1). The oligoclase gneiss is 


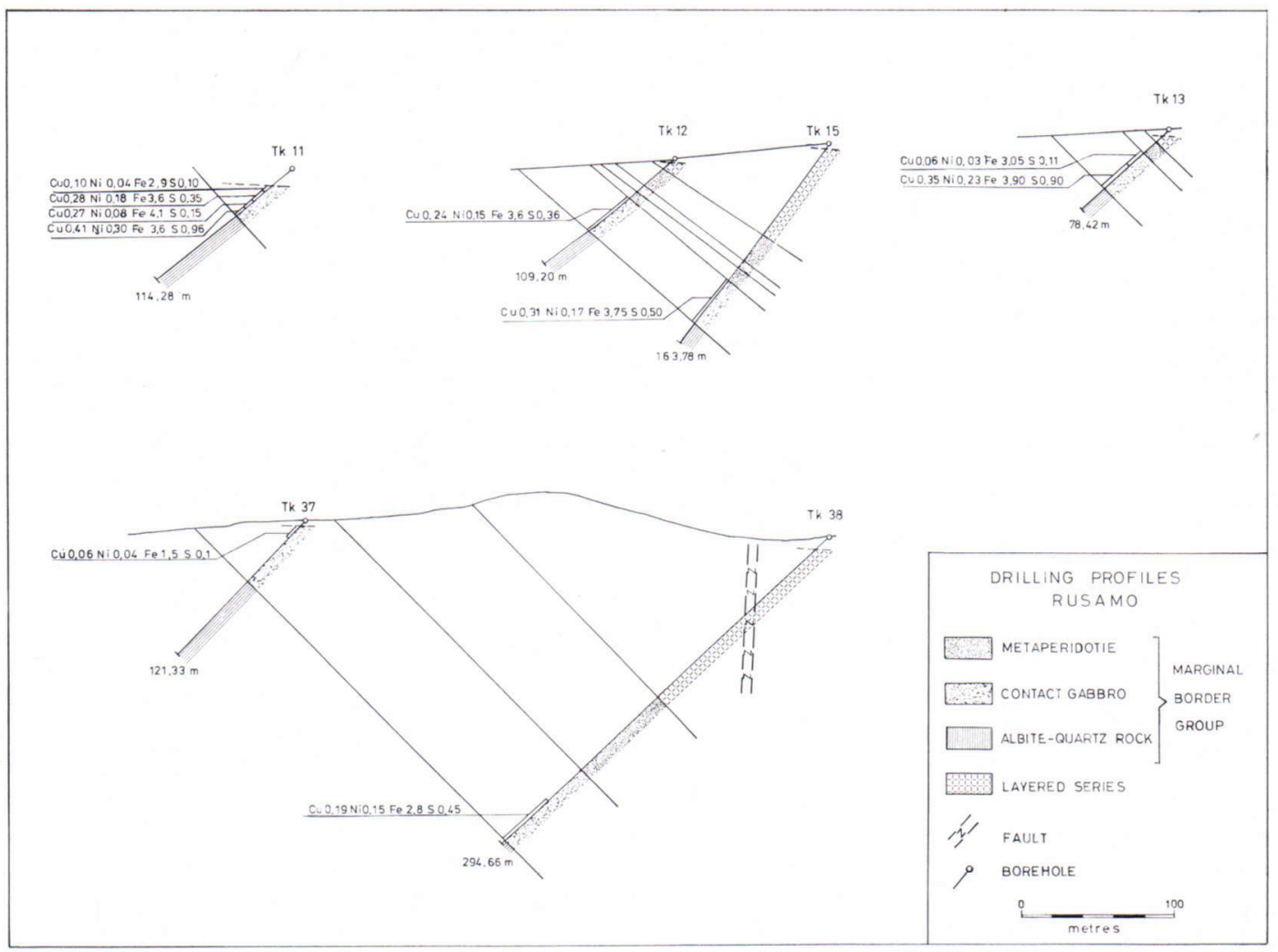

Fig. 7. The structure of the marginal border group at Rusamo based on the diamond drill-holes of Outokumpu Co. The drill-holes are marked on the map of the marginal border group (Fig. 3).

heterogeneous containing different kinds of inclusions, of which amphibolites may cover wide areas. The amphibolites and oligoclase gneisses of the basement complex are cut by granites.

The gneissose rock types of the basement complex grade, towards the basic body into albite-quartz rocks, which at first clearly display structures typical of the basement complex. Close to the intrusion these structures disappear, and the rock grades into a homogeneous, allotriomorphic-granular albitequartz rock, that may occur as dykes cutting the mafic rocks of the border zone.

Higher up, mafic portions appear in the albite-quartz rock. Their amount increases rapidly until a mafic rock, that contains albite-quartz rock only as hazy streaks and veinlets, is reached (Fig. 9, Fig. 10). This rock type is called the contact gabbro. It is also heterogeneous in its grain size, which varies from fine to coarse. Similarly, its chemical composition varies from ultrabasic to basic, and in some indeterminate blotches and pegmatitic veins, is even acidic. However, olivine normative gabbros predominate (Table 1 and Fig. 8), where the plagioclase is hypidiomorphic and the uralite (pseudomorph of pyroxene) is poikilitic. In places, in the contact gabbro, there are skeletal relics of ilmenomagnetite.

The same ultramafitolites, which can occur as inclusions in the contact gabbro, form a uniform layer above it. This ultramafitolite 

Table 1. Analyses of the contact gabbros, albite-quartz rocks, and oligoclase gneiss and the average composition of the layered series of the
Porttivara massif, with C.I.P.W. norms.

\begin{tabular}{|c|c|c|c|c|c|c|c|c|c|c|c|c|c|}
\hline & & 1 & 2 & 3 & 4 & 5 & 6 & 7 & 8 & 9 & 10 & 11 & 12 \\
\hline $\mathrm{SiO}_{2}$ & & 46.64 & 47.99 & 48.24 & 47.44 & 47.68 & 50.57 & 48.75 & 47.18 & 67.10 & 67.47 & 71.72 & 51.35 \\
\hline $\mathrm{TiO}_{2}$ & & 0.13 & 0.17 & 0.18 & 0.13 & 0.13 & 0.18 & 0.13 & 0.11 & 0.15 & 0.20 & 0.28 & 0.64 \\
\hline $\mathrm{Al}_{2} \mathrm{O}_{3}$ & & 15.78 & 16.24 & 17.31 & 13.70 & 13.55 & 19.19 & 17.69 & 6.99 & 17.59 & 17.43 & 13.74 & 16.14 \\
\hline $\mathrm{Fe}_{2} \mathrm{O}_{3}$ & & 1.29 & 1.16 & 1.68 & 1.23 & 1.48 & 1.34 & 1.60 & 3.37 & 1.54 & 0.89 & 0.95 & 1.59 \\
\hline $\mathrm{FeO}$ & & 7.47 & 6.96 & 6.93 & 8.06 & 7.88 & 5.72 & 6.67 & 8.68 & 1.34 & 2.24 & 2.69 & 7.13 \\
\hline $\mathrm{MnO}$ & & 0.21 & 0.18 & 0.15 & 0.22 & 0.21 & 0.15 & 0.15 & 0.13 & 0.05 & 0.05 & 0.08 & 0.14 \\
\hline MgO & & 15.30 & 12.50 & 10.80 & 15.20 & 14.30 & 10.10 & 11.70 & 23.80 & 0.80 & 1.40 & 1.40 & 8.09 \\
\hline $\mathrm{CaO}$ & & 5.27 & 7.47 & 8.01 & 6.14 & 7.26 & 6.97 & 4.85 & 2.93 & 6.11 & 4.20 & 3.77 & 9.48 \\
\hline $\mathrm{Na}_{2} \mathrm{O}$ & & 1.92 & 2.08 & 2.24 & 1.43 & 1.34 & 2.66 & 2.35 & 0.04 & 4.95 & 4.91 & 3.66 & 2.78 \\
\hline $\mathrm{K}_{2} \mathrm{O}$ & & 0.28 & 0.17 & 0.17 & 0.11 & 0.12 & 0.24 & 0.26 & 0.01 & 0.26 & 0.65 & 0.83 & 0.65 \\
\hline $\mathrm{H}_{2} \mathrm{O}^{+}$ & & 5.80 & 4.20 & 3.50 & 5.10 & 4.70 & 3.80 & 4.90 & 6.70 & 1.10 & 1.50 & 1.20 & $13 \quad 1.50$ \\
\hline $\mathrm{H}_{2} \mathrm{O}-$ & & 0.27 & 0.14 & 0.08 & 0.09 & 0.09 & 0.13 & 0.21 & 0.57 & 0.04 & 0.12 & 0.06 & 1.50 \\
\hline $\mathrm{P}_{2} \mathrm{O}_{5}$ & & 0.02 & n.d. & n.d. & n.d. & n.d. & n.d. & 0.02 & 0.02 & 0.02 & 0.07 & 0.09 & \\
\hline $\mathrm{S}$ & & n.d. & n.d. & 0.82 & 0.02 & 0.29 & 0.33 & 0.17 & 0.02 & 0.02 & 0.01 & 0.09 & \\
\hline Total & & 100.38 & 98.99 & 100.11 & 98.87 & 99.08 & 101.38 & 99.45 & 100.55 & 101.07 & 101.14 & 100.55 & 99.49 \\
\hline $\mathrm{Ni}$ & & 0.070 & 0.063 & 0.210 & 0.070 & 0.135 & 0.156 & 0.141 & 0.140 & 0.004 & 0.004 & 0.006 & \\
\hline $\mathrm{Cu}$ & & 0.010 & 0.008 & 0.230 & 0.021 & 0.156 & 0.142 & 0.140 & 0.034 & 0.004 & 0.002 & 0.005 & \\
\hline Co & & 0.009 & 0.006 & 0.010 & 0.007 & 0.010 & 0.011 & 0.008 & 0.010 & 0.002 & 0.002 & 0.003 & \\
\hline Q & & & & & & & & 1.30 & & 23.73 & 24.10 & 35.59 & \\
\hline Or & & 1.65 & 1.00 & 1.00 & 0.65 & 0.71 & 1.42 & 1.54 & 0.06 & 1.54 & 3.84 & 4.90 & 3.84 \\
\hline $\mathrm{Ab}$ & & 16.24 & 17.60 & 18.95 & 12.10 & 11.76 & 22.51 & 19.88 & 0.34 & 41.88 & 41.55 & 30.97 & 23.52 \\
\hline An & & 26.02 & 34.47 & 36.68 & 30.46 & 30.38 & 34.58 & 23.93 & 14.40 & 25.01 & 20.38 & 18.12 & 29.64 \\
\hline Cor & & 2.78 & & & 0.07 & & 1.88 & 4.77 & 1.63 & & 1.18 & 0.18 & \\
\hline Di & & & 2.08 & 2.47 & & 4.53 & & & & 4.19 & & & 14.11 \\
\hline & En & 23.52 & 19.41 & 17.98 & 27.78 & 27.20 & 24.94 & 29.14 & 57.21 & 0.65 & 3.49 & 3.49 & 13.53 \\
\hline Ну & Fs & 7.92 & 7.40 & 7.56 & 10.63 & 10.25 & 9.30 & 10.99 & 12.76 & 0.34 & 3.14 & 3.84 & 7.37 \\
\hline & Fo & 10.22 & 7.71 & 5.67 & 6.36 & 4.79 & 0.15 & & 1.61 & & & & 1.54 \\
\hline O1 & $\{\mathrm{Fa}$ & 3.79 & 3.24 & 2.63 & 2.59 & 1.99 & 0.06 & & 0.40 & & & & 0.92 \\
\hline Mt & & 1.87 & 1.68 & 2.44 & 1.78 & 2.15 & 1.94 & 2.32 & 4.89 & 2.23 & 1.29 & 1.38 & 2.31 \\
\hline Ap & & 0.05 & & & & & & 0.05 & 0.05 & 0.05 & 0.16 & 0.21 & \\
\hline Ilm & & 0.25 & 0.32 & 0.34 & 0.25 & 0.25 & 0.34 & 0.25 & 0.21 & 0.28 & 0.38 & 0.35 & 1.22 \\
\hline
\end{tabular}

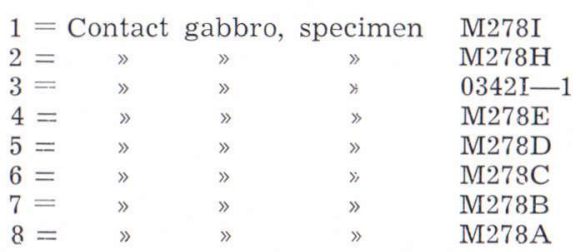

$$
\begin{aligned}
& 9=\text { Albite-quartz rock » T243 }
\end{aligned}
$$

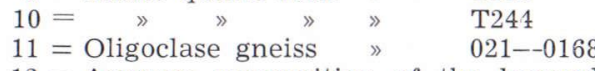

$$
\begin{aligned}
& 12=\text { Average composition of the layered } \\
& \text { series of the Porttivaara massif on } \\
& \text { the basis of } 165 \text { analyses (Mäkelä } \\
& \text { 1975). } \\
& \text { n.d. }=\text { not detected }
\end{aligned}
$$

Analyses 1-11 were carried out at the Research Laboratory of the Raahe Steel Works of Rautaruukki Co. 


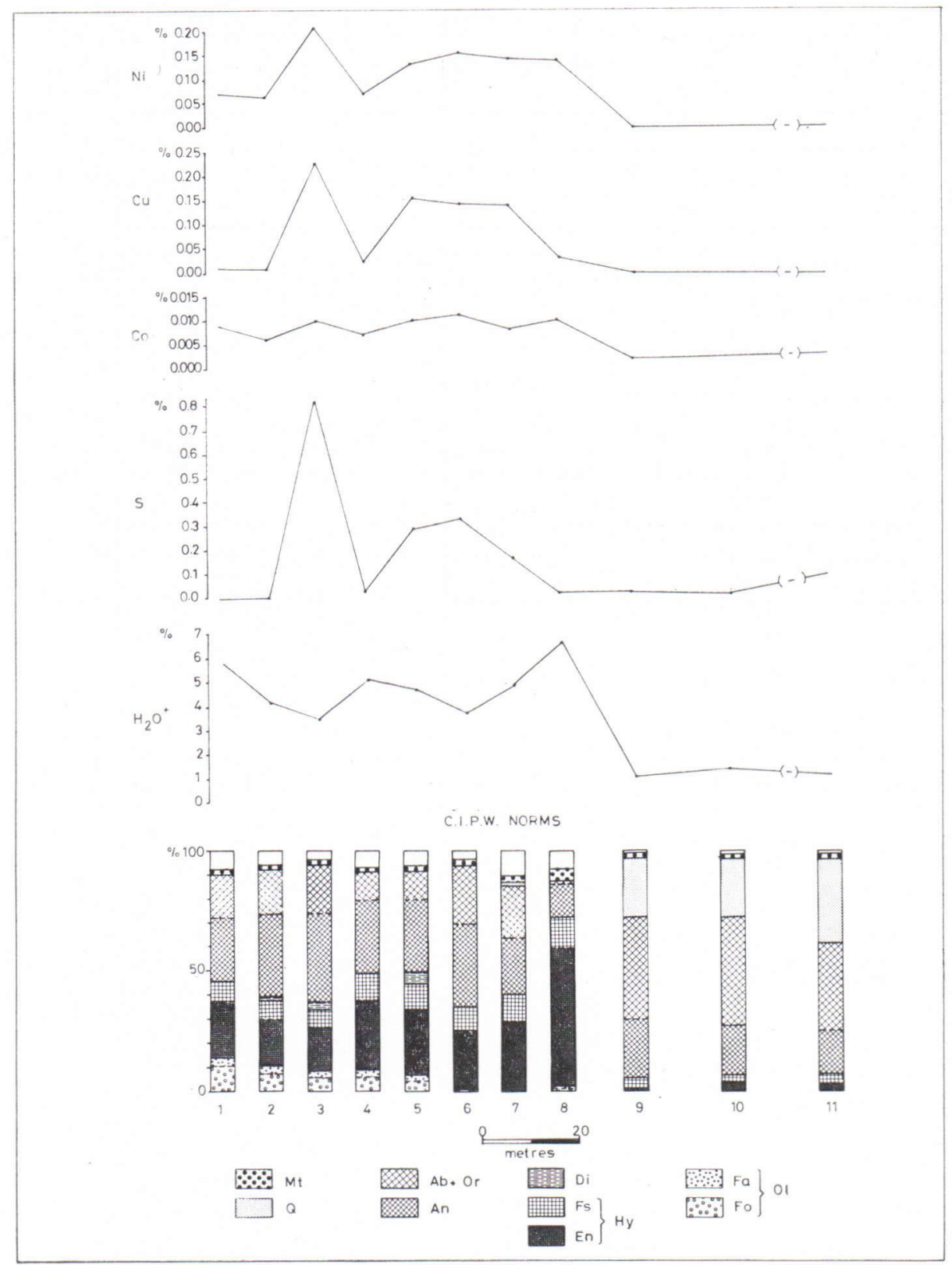

Fig. 8. The distribution of $\mathrm{Ni}, \mathrm{Cu}, \mathrm{Co}, \mathrm{S}$, and $\mathrm{H}_{2} \mathrm{O}+$ compared with C.I.W.P. norms in a profile across the marginal border group at Rusamo. Specimens 1-8 represent contact gabbro, 9-10 albite-quartz rock and 11 oligoclase gneiss. The numbering coresponds to table 1 .

layer is a metaperidotite at the bottom and a metapyroxenite at the top. The ultramafitolites are included in the marginal border group, and only above them does one find the rock types of the layered sequence, that crystallized following Fenner's series. 


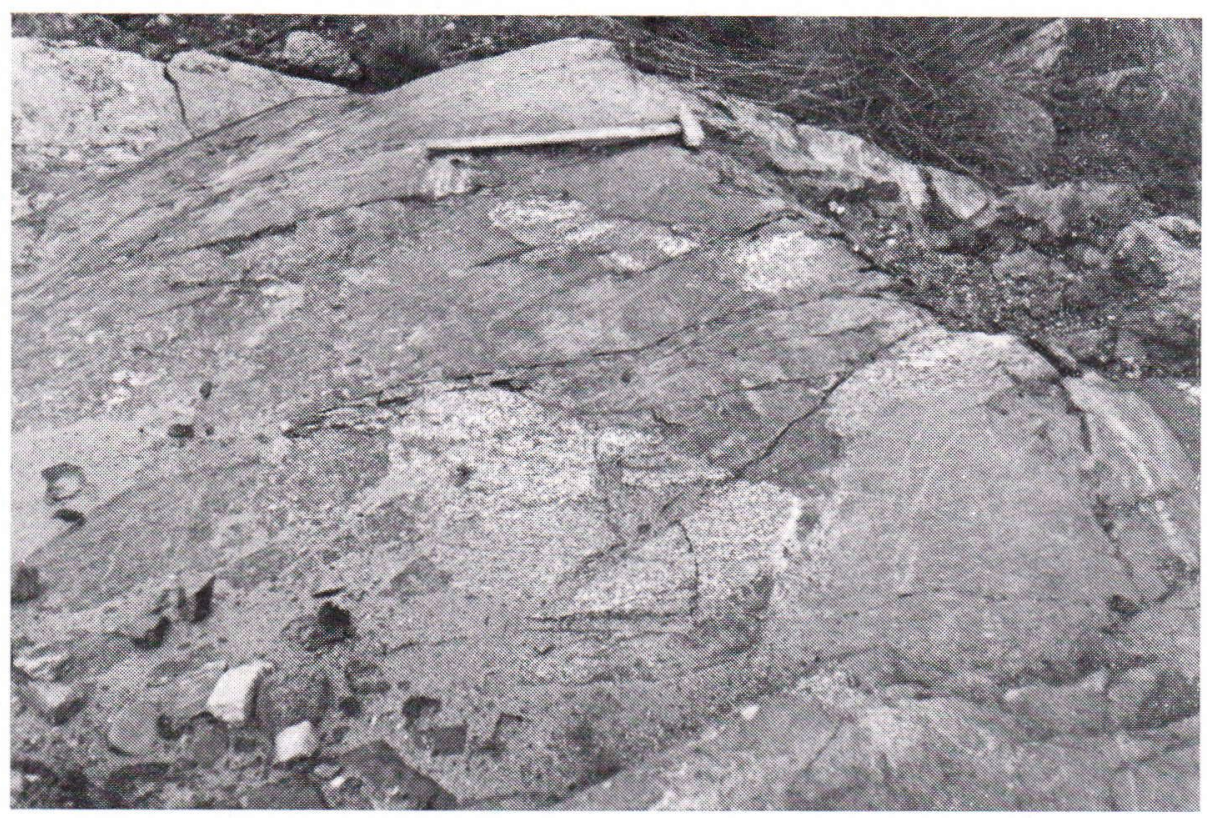

Fig. 9. Albite-quartz rock inclusions in the contact gabbro.

\section{Sulphide dissemination in the marginal border group}

The marginal border group is characterized by the dissemination of sulphides. The best dissemination is encountered at the top of the contact gabbro, where it takes the form of unevenly distributed cloud-like enrichments. In some places the zone is relatively rich in sulphides, in others the sulphides may be practically missing. There is no distinct boundary between disseminated and barren rock. In addition to the contact gabbro, sulphides also occur in places in the metaperidotite, and in the intermixture of contact gabbro and albite-quartz rock, but mineralization did not continue into the layered sequence nor into the albite-quartz rock underlying the contact gabbro. Fig. 8 shows the distribution of $\mathrm{Ni}, \mathrm{Cu}, \mathrm{Co}, \mathrm{S}$ and $\mathrm{H}_{2} \mathrm{O}^{+}$ compared with the C.I.P.W. norms in a profile across the marginal border group.

The constituent minerals of the sulphide dissemination are as follows: Chalcopyrite, pentlandite, pyrrhotite and pyrite. If pyrrhotite is absent, millerite may occur as a constituent mineral. The following accessory minerals have been identified: Covellite, violarite, marcasite, sphalerite, mackinawite, argentian pentlandite, hessite, gold, merenskite, froodite, michenerite and sperrylite. The sulphides occur as droplets with diameters of $0.5-2 \mathrm{~cm}$ and as a fine grained chalcopyrite dissemination. The droplets are mainly concentrated around albite-quartz blotches and streaks (Fig. 10).

\section{Chalcopyrite}

The main mineral of the sulphide dissemination is chalcopyrite. This often occurs in the sulphide droplets, usually at their centers, allotriomorphically between pyrite and pentlandite grains, and more often outside drop- 


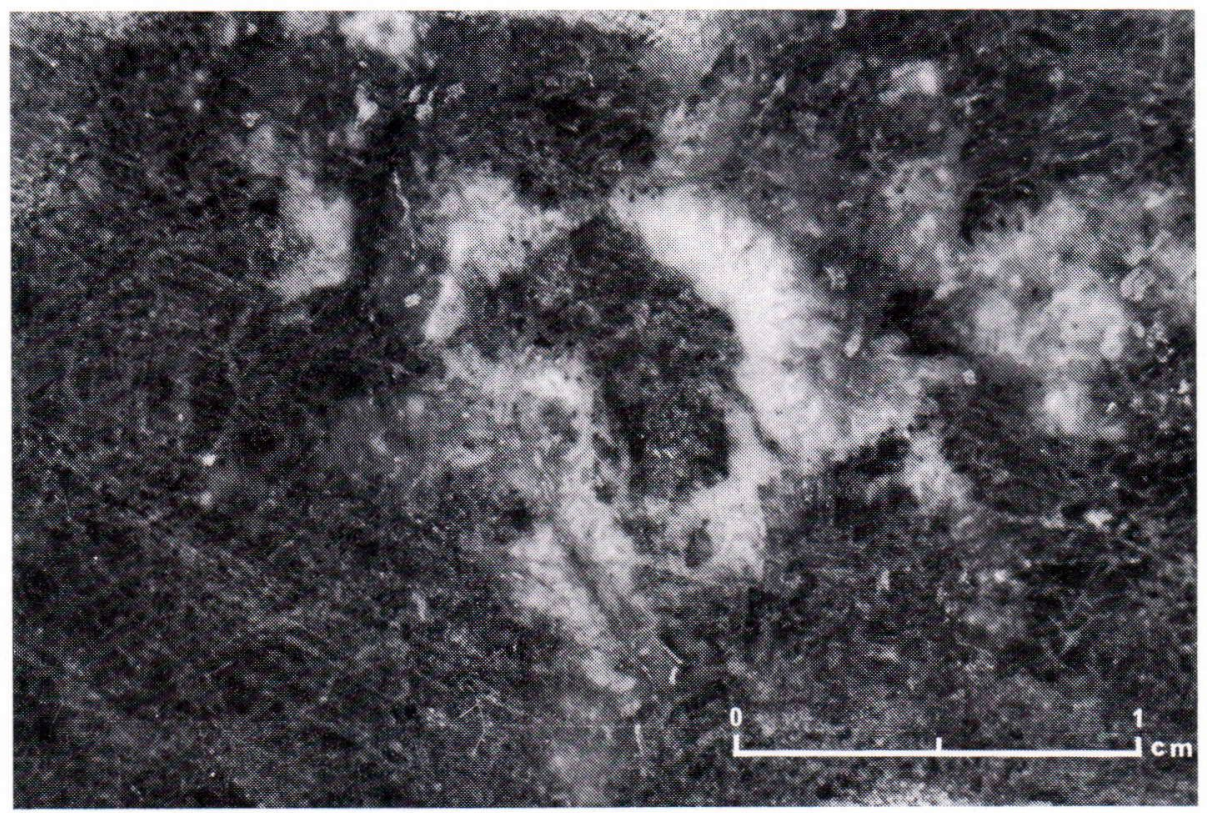

Fig. 10. A hazy albite-quartz inclusion with disseminated sulphides in the contact gabbro.

lets as a very fine grained dissemination partly as inclusions in uralite (Fig. 11). Chalcopyrite is partly altered to covellite. The compositions of chalcopyrite and covellite are indicated in table 2 .

\section{Pentlandite}

Pentlandite occurs as grains in the sulphide droplets together with pyrrhotite, chalcopyrite and pyrite (Fig. 12), and as small ex-

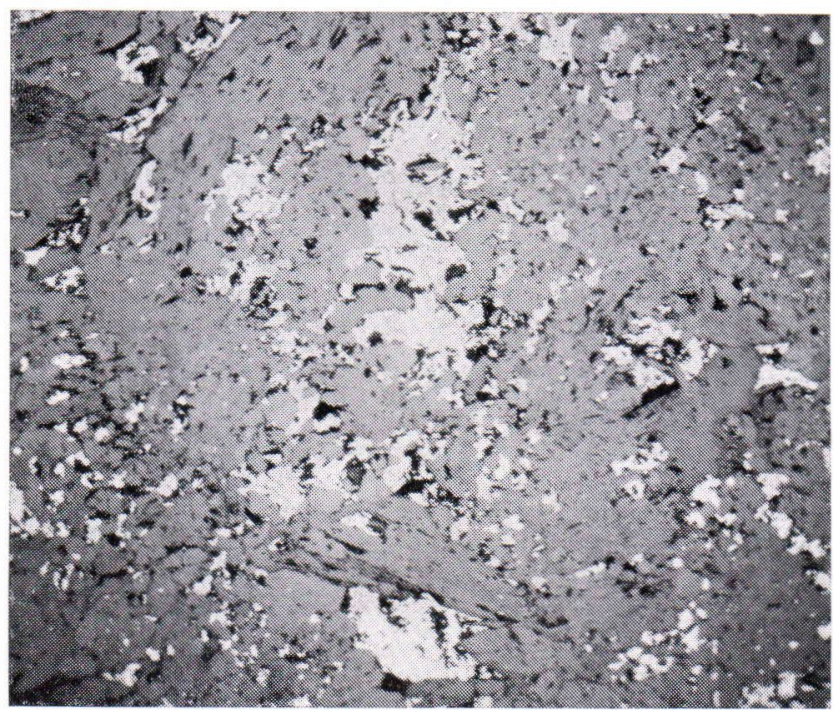

Fig. 11. Fine grained disseminated chalcopyrite (white) in the contact gabbro. Polished thin section. Magn. $30 \mathrm{x}$. 


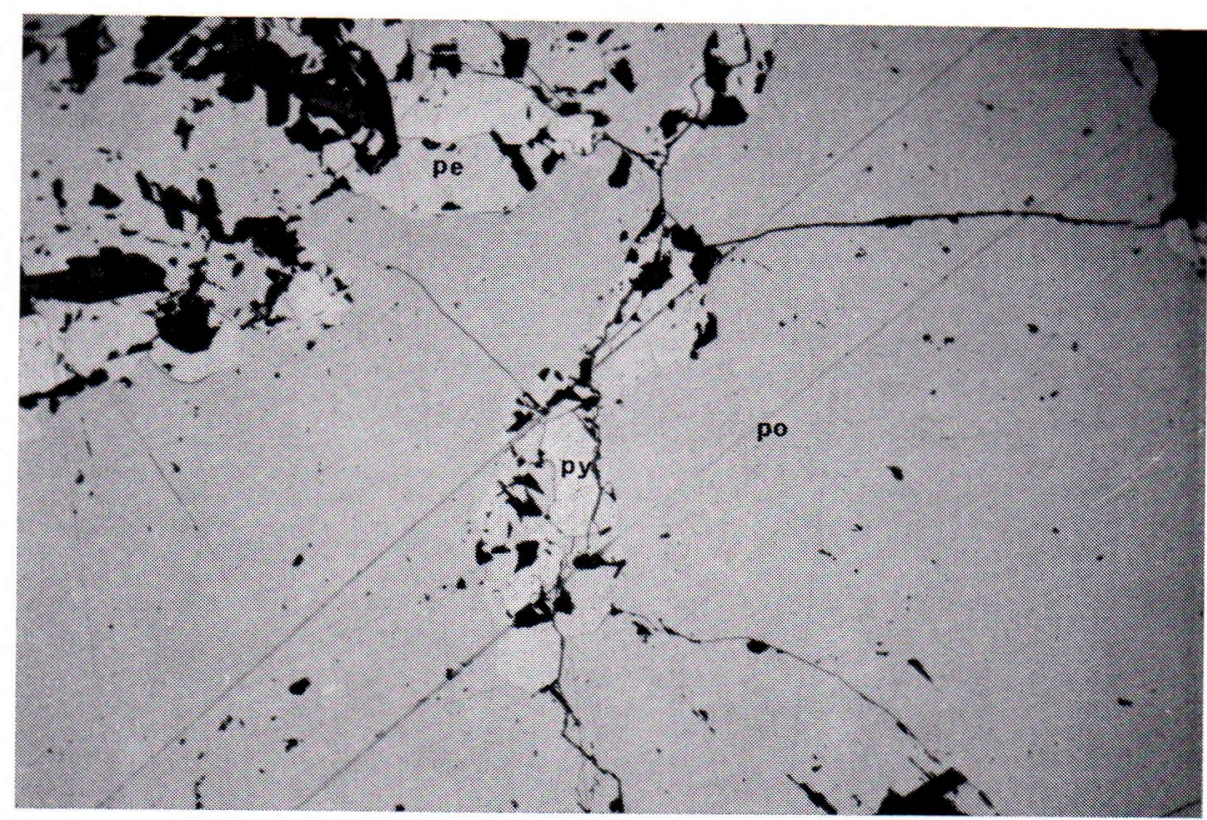

Fig. 12. Pyrrhotite (po), pentlandite (pe) and pyrite (py), in a sulphide droplet in the contact gabbro. Magn. $30 \mathrm{x}$.

solutions in the pyrrhotite, which surrounds the droplets. Moreover, pentlandite occurs as wide grains, $5-6 \mathrm{~mm}$ in diameter, inside which there often exist relics of pyrrhotite. The $\mathrm{Fe} /(\mathrm{Fe}+\mathrm{Ni})$-ratio of pentlandite varies within the range $0.427-0.468$ (Table 2). Iron rich members are found in pyrite bearing parageneses.

\section{Pyrrhotite}

Pyrrhotite forms the outer rim in the sulphide droplets (Fig. 12), and occurs as separate grain clusters together with pentlandite. The crystal structure of pyrrhotite is monoclinic. Its Ni-content is relatively high, over $0.45 \%$, and Co-content low, about $0.05 \%$ (Table 2). The pyrrhotite is partly altered to pyrite and marcasite.

\section{Pyrite}

Pyrite occurs as more idiomorphic grains than the other sulphides. These grains are often surrounded by a porous pyrite. Pyrite occurs together with pentlandite and chalcopyrite inside the concentric sulphide droplets, where it may form a myrmekitic texture with chalcopyrite. The Co-content of pyrite is high, often over $2 \%$ (Table 2).

\section{Pt-Pd-minerals}

The sulphide disseminated rocks contain some $\mathrm{Pd}$ and $\mathrm{Pt}$. Their total concentration may be up to $1 \mathrm{ppm}$. The $\mathrm{Pt} /(\mathrm{Pt}+\mathrm{Pd})$-ratio varies from $0.2-0.6$. The following $\mathrm{Pt}-\mathrm{Pd}-$ minerals have been identified: merenskite, froodite, michenerite and sperrylite. They cccur as small inclusions mainly in chalcopyrite and pyrrhotite.

\section{The genesis of the marginal border group} and the related sulphide dissemination.

As the basic magma intruded between the Archean gneisses and the overlying volcanics, 
Table 2. Microprobe analyses of sulphides in the marginal border group of the Porttivaara massif. Analyses were carried out at the Institute of Electron Optics, University of Oulu.

\begin{tabular}{|c|c|c|c|c|c|c|c|c|c|c|c|}
\hline & 1 & 2 & 3 & 4 & 5 & 6 & 7 & 8 & 9 & 10 & 11 \\
\hline $\mathrm{Zn}$ & n.d. & 0.01 & n.d. & n.d. & n.d. & 0.01 & 0.01 & 0.02 & 0.03 & 0.02 & n.d. \\
\hline $\mathrm{Cu}$ & n.d. & n.d. & 32.8 & 33.2 & 70.0 & 0.11 & 0.17 & 0.01 & n.d. & 0.01 & 0.44 \\
\hline $\mathrm{Ni}$ & 35.2 & 38.5 & 0.02 & 0.02 & 0.26 & 0.47 & 0.69 & 0.78 & 0.47 & 0.06 & 0.03 \\
\hline Co & 0.61 & 0.95 & 0.03 & 0.04 & 0.07 & 0.04 & 0.05 & 0.05 & 0.04 & 1.21 & 2.14 \\
\hline $\mathrm{Fe}$ & 31.0 & 28.7 & 30.6 & 30.6 & n.d. & 61.7 & 59.1 & 59.1 & 59.5 & 47.0 & 44.5 \\
\hline $\mathrm{S}$ & 33.4 & 32.2 & 34.1 & 34.1 & 27.8 & 40.0 & 38.7 & 38.9 & 40.0 & 52.6 & 51.5 \\
\hline Total & 100.21 & 100.36 & 97.55 & 97.96 & 98.13 & 102.33 & 98.72 & 98.86 & 100.04 & 100.90 & 98.61 \\
\hline
\end{tabular}

1 = pentlandite, specimen M278D

$2=$ » $\quad$ M295

3 = chalcopyrite, $\quad$ M278H

» M295

$5=$ covellite, $\quad \gg \quad$ M278C

6 = pyrrhotite, $\quad$ $\quad$ M278D
$7=$ pyrrhotite, specimen $\mathrm{M} 278 \mathrm{H}$

$8=$ » $\gg$ M295

$9=\quad$ » $1278 \mathrm{C}$

$10=$ pyrite, $\quad$ M278D

n.d. $=$ not detected 


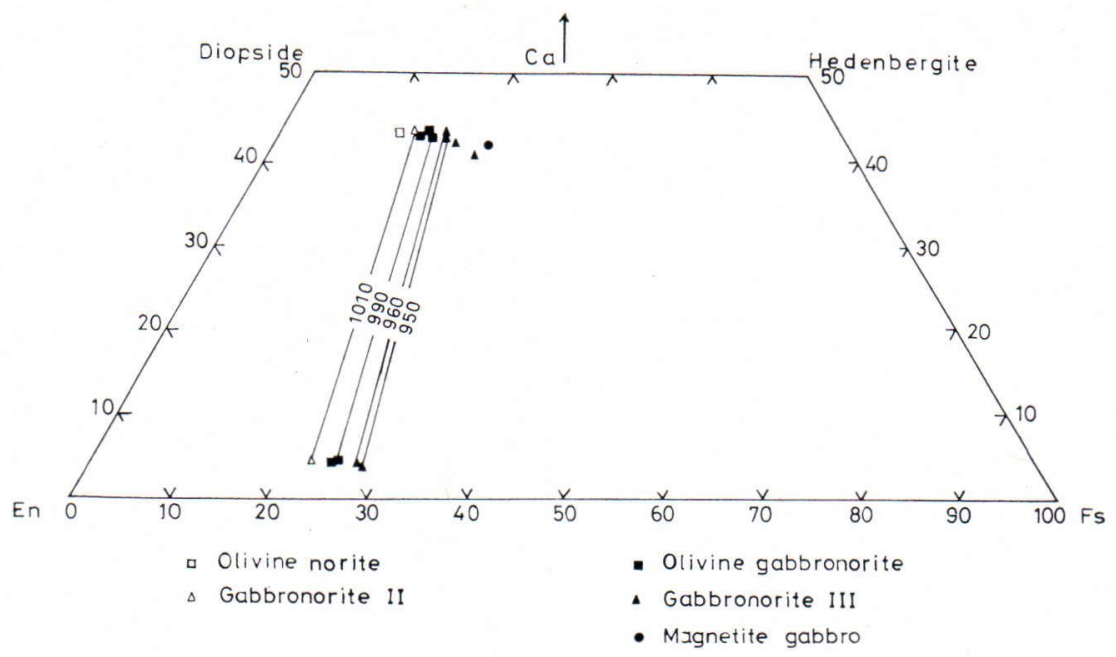

Fig. 13. The crystallization trend for the pyroxenes in the layered series of the Porttivaara massif, based on microprobe analyses (Table 3), and estimated equilibration temperatures $\left({ }^{\circ} \mathrm{C}\right.$ ) for pyroxenes. Temperatures calculated according to Wood and Banno (1973).

a. $2 \mathrm{~km}$ thick lopolith was formed with two essential parts: a wide layered inner part and a relatively thin border zone. The marginal border group is composed of a heterogeneous, sulphide disseminated contact gabbro, metaperidotite and albite-quartz rock. In order to understand the reason for the existence of the sulphide dissemination in the border zone, attention must also be paid to the inner parts of the intrusion.

The inside of the intrusion was formed as a closed system, which, with decreasing temperature, crystallized according to Fenner's series producing olivine and pyroxene gabbros and magnetite gabbros, while at the same time plagioclase cumulated in the upper parts as anorthositic gabbros. In the light of Osborn's (1959) experimental work, the crystallization order of the intrusion indicates, that the water content and the fugacity of oxygen were low in the magma, especially at the beginning of crystallization. A hot, dry magma is also indicated by the fact that the crystallization took place at a high tem- perature within a relatively narrow temperature interval (Table 3, Figs. 6 and 13). Even though the amount of magma was great, the total amount of differentiation was small.

When the hot, dry magma made its way, in a cool environment, between the basement complex and the volcanics, its borders chilled and crystallized rapidly. Brecciation took place simultaneously, and different alien blocks mixed with the crystallizing magma. An open system developed at the border zone, where interaction took place between the magma and its surroundings. As a result of this contamination the fugacity of oxygen rose, which led to the crystallization of ilmenomagnetite in the border zone and to the cumulation of $\mathrm{Mg}-\mathrm{Fe}$-silicates above the partly molten border zone. Altogether these coincidences lowered decisively the solubility of the sulphides in the magma causing the generation of a sulphide melt, which was enriched in the contact gabbro.

The thermal effect of the intrusion melted alien blocks mixed with the border zone. 
Table 3. Microprobe analyses of olivines and pyroxenes in the layered series and structural formulae calculated on the basis of 4 oxygen atoms for olivines and 6 oxygen atoms for pyroxenes. Analyses were carried out at the Institut of Electron Optics, University of Oulu.

\begin{tabular}{|l|c|c|c|c|c|c|c|c|c|}
\hline & 1 Ol & 3 Ol & 4 Ol & 5 Ol & 2 Opx & 4 Opx & 5 Opx & 6 Opx & 7 Opx \\
\hline $\mathrm{SiO}_{2}$ & 39.7 & 38.6 & 37.8 & 39.0 & 53.9 & 53.6 & 53.9 & 53.5 & 52.9 \\
$\mathrm{TiO}_{2}$ & 0.01 & 0.02 & 0.02 & 0.04 & 0.23 & 0.14 & 0.29 & 0.17 & 0.17 \\
$\mathrm{Al}_{2} \mathrm{O}_{3}$ & 0.14 & 0.04 & 0.11 & 0.06 & 1.40 & 1.11 & 1.15 & 1.15 & 1.27 \\
$\mathrm{Cr}_{2} \mathrm{O}_{3}$ & n.d. & n.d. & n.d. & n.d. & 0.21 & 0.06 & 0.05 & 0.19 & 0.17 \\
$\mathrm{FeO}$ tot & 23.5 & 28.0 & 27.0 & 27.9 & 14.4 & 15.8 & 16.2 & 17.0 & 20.7 \\
$\mathrm{MnO}$ & 0.27 & 0.36 & 0.38 & 0.29 & 0.31 & 0.35 & 0.31 & 0.32 & 0.40 \\
$\mathrm{MgO}$ & 39.5 & 34.1 & 37.5 & 35.1 & 26.8 & 26.2 & 26.2 & 24.6 & 23.4 \\
$\mathrm{CaO}$ & 0.10 & 0.09 & 0.09 & 0.14 & 2.13 & 2.08 & 2.22 & 2.00 & 1.61 \\
\hline total & 103.22 & 101.21 & 102.90 & 102.53 & 99.38 & 99.34 & 100.32 & 98.93 & 100.62 \\
$\mathrm{Si}$ & 1.002 & 1.016 & 0.977 & 1.012 & 1.955 & 1.958 & 1.953 & 1.972 & 1.950 \\
$\mathrm{Al}$ & - & - & - & - & 0.045 & 0.042 & 0.047 & 0.028 & 0.050 \\
$\mathrm{Al}$ & 0.004 & 0.001 & 0.003 & 0.002 & 0.015 & 0.006 & 0.002 & 0.022 & 0.005 \\
$\mathrm{Ti}$ & 0.000 & 0.000 & 0.000 & 0.001 & 0.006 & 0.004 & 0.008 & 0.005 & 0.005 \\
$\mathrm{Cr}$ & - & - & - & - & 0.006 & 0.002 & 0.001 & 0.006 & 0.005 \\
$\mathrm{Fe}+$ & 0.496 & 0.616 & 0.584 & 0.605 & 0.437 & 0.483 & 0.491 & 0.524 & 0.638 \\
$\mathrm{Mn}$ & 0.006 & 0.008 & 0.008 & 0.006 & 0.010 & 0.011 & 0.010 & 0.010 & 0.012 \\
$\mathrm{Mg}$ & 1.486 & 1.338 & 1.445 & 1.357 & 1.449 & 1.427 & 1.415 & 1.351 & 1.286 \\
$\mathrm{Ca}$ & 0.003 & 0.003 & 0.002 & 0.004 & 0.083 & 0.081 & 0.086 & 0.079 & 0.064 \\
$\mathrm{Fo}$ & 75.0 & 68.5 & 71.2 & 69.2 & - & - & - & - & - \\
$\mathrm{Fa}$ & 25.0 & 31.5 & 28.8 & 30.8 & - & - & - & - & - \\
$\mathrm{En}$ & - & - & - & - & 73.3 & 71.3 & 70.7 & 68.8 & 64.3 \\
$\mathrm{Fs}$ & - & - & - & - & 22.6 & 24.7 & 25.0 & 27.2 & 32.5 \\
$\mathrm{Wo}$ & - & - & - & - & 4.2 & 4.1 & 4.3 & 4.0 & 3.2 \\
$100 \mathrm{Mg} /$ & - & - & - & - & 76.4 & 74.3 & 73.9 & 71.7 & 66.4 \\
$(\mathrm{Mg}+\mathrm{Fe}+\mathrm{Mn})$ & - & - & & & & &
\end{tabular}

$\mathrm{Ol}=$ Olivine

Opx $=$ Ca-poor pyroxene

$\mathrm{Cpx}=$ Ca-rich pyroxene

1 = Olivine norite, specimen W112-1

$2=$ Gabbronorite II, specimen W047

3 = Olivine gabbronorite, specimen M197B

$4 \quad=$ Olivine gabbronorite, specimen W351

$5=$ Olivine gabbronorite, specimen W059

$6=$ Gabbronorite III, specimen W060

$7=$ Gabbronorite III, specimen W201A

$8=$ Gabbronorite III, specimen M133

$9=$ Gabbronorite III, specimen M155

10 = Magnetite gabbro, specimen M327

n.d. = not determined

The obligoclase gneisses of the basement complex were altered and partly remobilized adjacent to the intrusion. With a lowering of the temperature the material thus generated crystallized as albite-quartz rocks between the basement complex and the contact gabbro, and as hazy streaks and veinlets within the contact gabbro. The sulphide melt was present in all the stages of the contact zone and reached equilibrium at a low temperature.

The sulphide melt was generated contemporaneously with the intrusion of the magma, and the inner parts of the intrusion crystallized afterwards in a closed system, which did not yield conditions in which the 
Table 3. Microprobe analyses of olivines and pyroxenes - continued

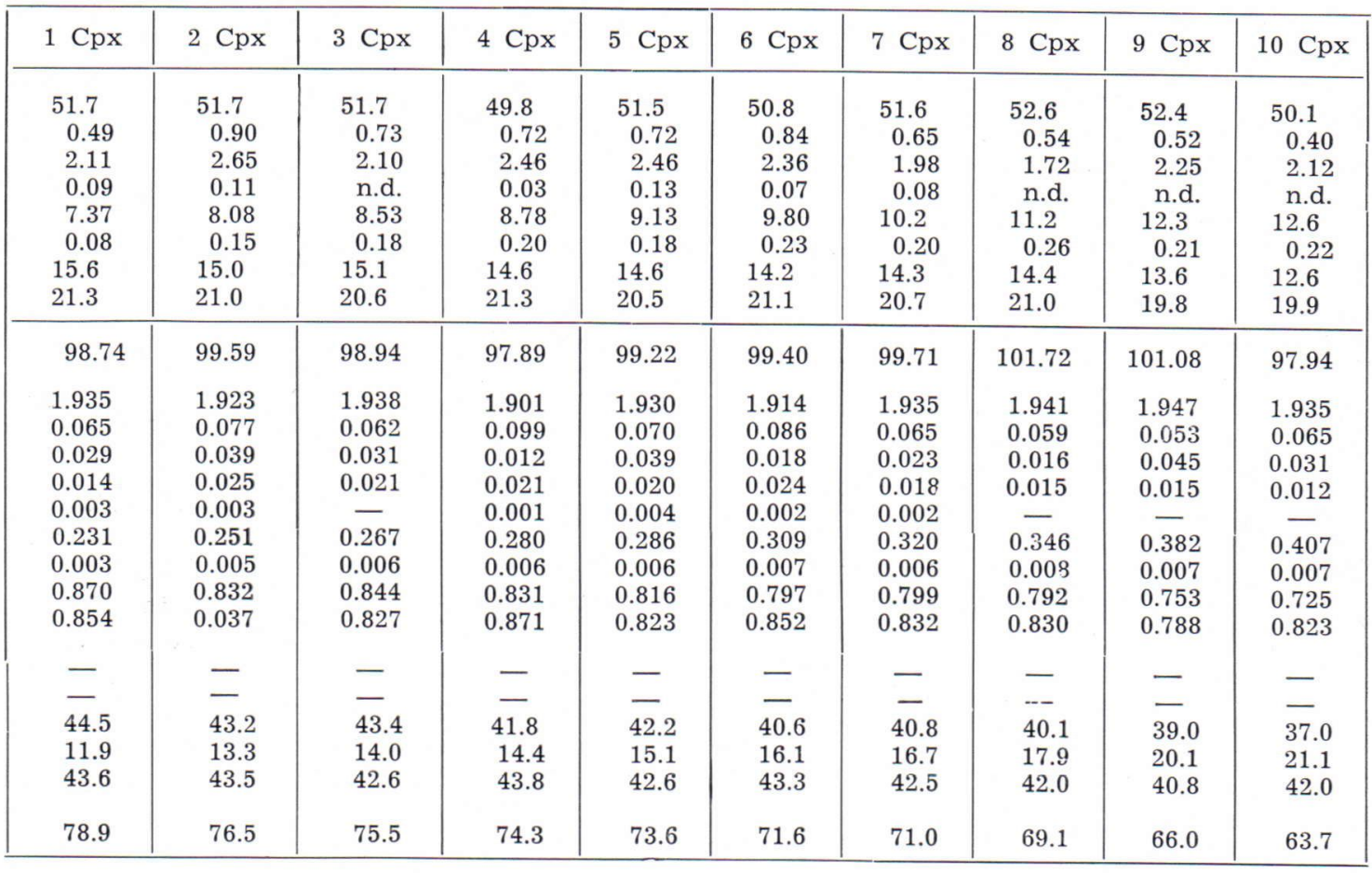

sulphide melt could have separated from the silicate melt as an immiscible sulphide liquid. Only an open system in the marginal border group was able to decrease the solu- bility of the sulphides in the magma to produce a sulphide melt. The separation of sulphides is, therefore, no longer detectable in the rocks of the layered sequence.

\section{References}

Häkli, T. A. (1971) Silicate nickel and its application to the exploration of nickel ores. Bull. Geol. Soc. Finland 43: 247-263.

Haughton, D. R., Roeder, P. L. and Skinner, B. J. (1974) Solubility of sulfur in mafic magmas. Econ. Geol. 69: 451-467.

Isohanni, M. (1976) Porttivaaran ja Syötteen emäksisten kerrosintruusioiden sisäisestä sulfidimuodostuksesta Koillismaalla. Licentiate thesis. Manuscript at the Department of Geology, University of Oulu, Finland.

Juopperi, A. (1970) Porttivaaran emäksisen intrusiivin kiteytyminen ja siihen liittyvän titaani- rautamalmin synty Fe:n, Mg:n, Ti:n ja V:n jakaantumisen valossa. Master's thesis. Manuscript at the Department of Geology, University of Oulu, Finland.

Juopperi, A. (1977) The magnetite gabbro and related Mustavaara vanadium ore deposit in the Porttivaara layered intrusion, north-eastern Finland. Geol. Surv. Finland Bull. 288.

Kerkkonen, O. (1976) Koillismaan emäksisten intrusiivien jalkapuolen reunavyöhykkeen sulfidimineralisaatio ja sen synty. Master's thesis. Manuscript at the Department of Geology, 
University of Oulu, Finland.

Maclean, W. H. (1969) Liquidus phase relations in the $\mathrm{FeS}-\mathrm{FeO}-\mathrm{Fe}_{3} \mathrm{O}_{4}-\mathrm{SiO}_{2}$ system and their application in geology. Econ. Geol. 64: 865884.

Mäkelä, T. (1975) Emäksisen magman kiteytyminen ja differentiaatio Porttivaaran alueella, Koillismaalla. Master's thesis. Manuscript at the Department of Geology, University of Oulu, Finland.

Matisto, A. (1958) Suomen geologinen yleiskartta. The General Geological Map of Finland. LehtiSheet D5. Kivilajikartan selitys. Explanation to the Map of Rocks. With an English Summary.

Ohenoja, V. (1968) Porttivaaran-Kuusijärven alueen kallioperä. Master's thesis. Manuscript at the Department of Geology, University of Oulu, Finland.

Osborn, E. F. (1959) Role of oxygen pressure in the crystallization and differentiation of basaltic magma. Am. J. Sci. 257: 609-647.

Pirainen, T. and Juopperi, A. (1968) Die Titaneisenerzlagerstätte von Porttivaara und ihre Entstehung. Nordia 5.
Piirainen, T., Hugg, R., Isohanni, M. and Juopperi, A. (1974) On the geotectonics and ore forming processes in the basic intrusive belts of Kemi-Suhanko, and Syöte-Näränkävaara. Bull. Geol. Soc. Finland 46: 93-104.

Piirainen, T., Hugg, R., Aario, R., Forsström, L., Ruotsalainen, A. and Koivumaa, S. (1977) Koillismaan malmikriittisten alueiden loppuraportti. An English Summary: The report of the Koillismaa research project. Geol. Surv. Finland. Report of investigation (in press).

Shima, H. and Naldrett, A. J. (1975) Solubility of sulfur in an ultramafic melt and the relevance of the system Fe-S-O. Econ. Geol. 70: 960-967.

Simonen, A. (1960) Pre-Quaternary rocks in Finland. Bull. Comm. Géol. Finlande 191.

Streckeisen, A. (1976) To each plutonic rock its proper name. Earth-Sci. Rev. 12: 1-33.

Wood, B. J. and Banno, S. (1973) Garnet-orthopyroxene and orthopyroxene-clinopyroxene relationships in simple and complex systems. Contr. Mineral, and Petrol. 42: 109-124.

Manuscript received June 2, 1977. 